\title{
Konjungtivitis Vernalis
}

\author{
Siti Budiati Widyastuti, Sjawitri P. Siregar
}

Konjungtivitis vernalis (KV) merupakan inflamasi konjungtiva yang bersifat bilateral dan rekuren. Kelainan ini ditandai oleh papil cobblestone pada konjungtiva tarsal dan hipertrofi papil pada konjungtiva limbus. ${ }^{1-5}$ Insidens penyakit ini berkisar antara $0,1-0,5 \%$ diantara penyakit mata lainnya dan meningkat terutama pada musim kemarau. Penyakit ini umumnya terjadi pada anak berusia antara 3-25 tahun, dan lebih sering pada laki-laki. ${ }^{1-5}$

Lebih dari sembilan puluh persen pasien KV memiliki riwayat atopi pada dirinya maupun anggota keluarganya. Patogenesis dan etiologi penyakit ini belum diketahui dengan pasti. Beberapa peneliti menghubungkan dengan reaksi hipersensitivitas tipe I dan IV. ${ }^{2,4,6-8}$ Tata laksana adekuat untuk mencegah terjadinya kekambuhan sampai saat ini belum memberikan hasil yang memuaskan. ${ }^{1,6,8-10}$ Namun umumnya setelah 2 sampai 10 tahun akan terlihat resolusi gejala secara spontan., ${ }^{4,6}$,

Tujuan laporan kasus ini untuk membahas diagnosis dan tata laksana konjungtivitis vernalis.

Kata kunci: cobblestone dan hipertrofi konjungtiva, atopi

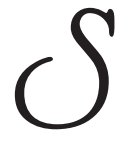

eorang anak laki-laki berusia 4 tahun datang pertama kali ke poliklinik Alergi-Imunologi Departemen Ilmu Kesehatan Anak (IKA) FKUI/RSUPNCM pada tanggal 2 Agustus 2003; dirujuk dari Bagian Ilmu Penyakit Mata dengan diagnosis konjungtivitis vernalis, kemungkinan alergi sebagai penyebab. Berdasarkan aloanamnesis dengan ibu pasien diketahui bahwa sejak 1 tahun yang lalu, pasien sering mengeluh kedua matanya gatal dan terlihat merah. Saat pagi hari terdapat banyak kotoran mata yang kental dan lengket. Kedua matanya terasa sangat gatal sehingga pasien sering menggosok-gosok matanya, akibatnya mata semakin berair dan merah. $\mathrm{Hal}$ ini bertambah berat saat pasien pulang sekolah atau setelah bermain di luar rumah di bawah terik

\footnotetext{
Alamat korespondensi:

Dr Sjawitri P. Siregar, Sp.A(K).

Divisi Alergi Imunologi. Departemen Ilmu Kesehatan Anak FKUI-RSCM. Jl. Salemba no. 6, Jakarta 10430.

Telepon: 021-3161144 Fax.021-3913982.
}

Dr. Siti Budiati Widyastuti. PPDS Dep. Ilmu Kesehatan Anak FKUI matahari. Gangguan penglihatan disangkal oleh ibu pasien. Kemudian pasien berobat ke dokter mata dan mendapat obat Fluorometolon + neomisin, tetes mata vitamin A, lodaxamide. Keluhan tersebut berkurang untuk sementara, namun timbul kembali. Pasien merupakan anak kedua dari tiga bersaudara. Gejala atopi pada pasien adalah rinitis alergi, paman menderita asma, dan kakak pasien alergi terhadap obat kotrimoksasol.

Pemeriksaan fisis saat masuk didapatkan anak sadar, tidak sesak, tidak sianosis. Berat badan $18 \mathrm{~kg}$ $\left(\mathrm{P}_{75-90} \mathrm{NCHS}\right)$ dan tinggi badan $102 \mathrm{~cm}\left(\mathrm{P}_{25-50} \mathrm{NCHS}\right)$. Laju denyut nadi sama dengan laju denyut jantung 84 $\mathrm{x} /$ menit, teratur, isi cukup. Laju napas $24 \mathrm{x} /$ menit, teratur, suhu aksila $37,2^{\circ} \mathrm{C}$. Pada mata kanan dan kiri tampak konjungtiva tarsalis superior hiperemis, terdapat hipertropi papil, dan bintik-bintik epitelial, tidak terdapat injeksi konjungtiva, ulkus maupun papil pada limbus. Pada mata kiri terlihat sikatriks di tengah kornea. Sklera tidak ikterik, dan pemeriksaan visus kedua mata $6 / 20$. Tonsil dan faring tidak ada kelainan. Pada paru, jantung dan abdomen tidak ditemukan kelainan. 
Pemeriksaan laboratorium menunjukkan kadar hemoglobin $11,6 \mathrm{~g} / \mathrm{dL}$, leukosit $9.400 / \mathrm{mL}$, eritrosit 4,37 juta/mL, hematokrit 34,2 vol\%, trombosit $310.000 / \mathrm{mL}$, hitung jenis: basofil $0 \%$, eosinofil $4 \%$, batang $0 \%$, segmen $73 \%$, limfosit $21 \%$, monosit $2 \%$. Laju endap darah $12 \mathrm{~mm} / \mathrm{jam}$. Pemeriksaan urin dan tinja dalam batas normal. Kadar IgE serum 98,2 IU/ $\mathrm{uL}(\mathrm{N}$ serum < $60 \mathrm{IU} / \mathrm{uL}$ ), kadar IgG serum $2500 \mathrm{mg} /$ $\mathrm{dL}\left(\mathrm{N} 1433-2150 \mathrm{mg} / \mathrm{dL}\right.$ ), eosinofil total $423 / \mu \mathrm{l}^{3}$ $\left(\mathrm{N}<300 / \mu l^{3}\right)$. Hasil pemeriksaan uji kulit positif 2 terhadap debu rumah, tungau debu rumah, udang, dan kapuk. Hasil pemeriksaan histopatologik scraping test dari konjungtiva didapatkan kesan proporsi sel eosinofil dan sel neutrofil meningkat. Saat itu direncanakan pemeriksaan IgE spesifik serum terhadap debu rumah dan tungau debu rumah, namun karena keterbatasan biaya hanya diperiksa kadar IgE spesifik serum terhadap tungau debu rumah yang menunjukkan nilai 135,2 IU/mL (normal < 0,35 IU/ $\mu \mathrm{L}$ ). Hasil uji tuberkulin negatif.

Pasien didiagnosis sebagai konjungtivitis vernalis dengan komplikasi keratitis pada mata kiri. Ditemukan penyebab alergi, kemungkinan tungau debu rumah. Pengobatan yang diberikan berupa penghindaran terhadap alergen penyebab (membersihkan rumah), pemakaian kacamata untuk mengurangi kontak pada mata, mengurangi kegiatan di luar rumah, pemberian prednison selama 7 hari, iodoksamide (stabilisator sel mast) topikal, vitamin A tetes mata, chlortrimetan $3 \times 2$ mg oral.

Satu minggu setelah pengobatan, keluhan gatal dan perih di mata sudah berkurang, pasien dianjurkan kontrol teratur ke poliklinik Alergi dan Imunologi Anak FKUI/ RSCM.

\section{Diskusi}

Konjungtivitis vernalis merupakan salah satu bentuk proses inflamasi kronik dan berulang pada mata, umumnya bilateral. ${ }^{4,5,8}$ Pasien dengan atopi mempunyai risiko lebih besar untuk menderita $\mathrm{KV}^{1-6}$ Konjungtivitis Vernalis dibedakan atas 3 tipe yaitu tipe palpebra, tipe limbus atau campuran keduanya. ${ }^{2,3}$

Prevalensi KV lebih tinggi di daerah tropis seperti Afrika, India, Mediteranian, Amerika Tengah dan Selatan, serta Timur Tengah. ${ }^{4,6,8} \mathrm{KV}$ lebih banyak terdapat pada kulit berwarna dibandingkan kulit putih. ${ }^{1-6}$ Penyakit ini lebih banyak didapatkan pada laki-laki dengan perbandingan $3: 10^{5,6}$ Sebagian besar pasien berusia antara 3-25 tahun. ${ }^{6}$

Pasien ini laki-laki, berusia 4 tahun, kulit berwarna, dan didapatkan riwayat atopi, menderita KV tipe palpebra. Berdasarkan data rekam medik IKA FKUI/ RSCM sejak tahun 1998 - 2003 di Poliklinik Subbagian Alergi dan Imunologi, terdapat KV sebanyak 22 kasus KV dengan perbandingan antara laki-laki dan perempuan $14: 8$. Etiologi KV sampai saat ini belum diketahui dengan pasti. ${ }^{9}$ Beberapa faktor penyebab diduga adalah alergen serbuk sari, debu, tungau debu rumah, bulu kucing, makanan, faktor fisik berupa panas sinar matahari atau angin. Reaksi alergi yang terjadi dapat disebabkan oleh satu atau lebih alergen atau bersamasama dengan faktor-faktor lain., 1,2,9

Patogenesis terjadinya kelainan ini belum diketahui secara jelas, tapi terutama dihubungkan dengan reaksi hipersensitivitas pada mata. Reaksi hipersensitivitas tipe I merupakan dasar utama terjadinya proses inflamasi pada KV. ${ }^{1,2,5,9}$ Pemeriksaan histopatologik dari lesi di konjungtiva menunjukkan peningkatan sel mast, eosinofil dan limfosit pada subepitel dan epitel. Dalam perjalanan penyakitnya, infiltrasi sel dan penumpukan kolagen akan membentuk papil raksasa. Penemuan ini menjelaskan bahwa KV bukan murni disebabkan oleh reaksi hipersensitivitas tipe I fase cepat, melainkan merupakan kombinasi tipe I dan IV. ${ }^{6}$ Bonini dkk, ${ }^{6}$ menemukan bahwa hiperreaktivitas non spesifik juga mempunyai peran dalam KV. Faktor lain yang berperan adalah aktivitas mediator non Ig E oleh sel mast. ${ }^{5}$ Reaksi hipersensitivitas tipe I dimulai dengan terbentuknya antibodi IgE spesifik terhadap antigen bila seseorang terpapar pada antigen tersebut. Antibodi IgE berperan sebagai homositotropik yang mudah berikatan dengan sel mast dan sel basofil. Ikatan antigen dengan antibodi IgE ini pada permukaan sel mast dan basofil akan menyebabkan terjadinya degranulasi dan dilepaskannya mediator-mediator kimia seperti histamin, slow reacting substance of anaphylaxis, bradikinin, serotonin, eosinophil chemotactic factor, dan faktor-faktor agregasi trombosit. Histamin adalah mediator yang berperan penting, yang mengakibatkan efek vasodilatasi, eksudasi dan hipersekresi pada mata. Keadaan ini ditandai dengan gejala seperti mata gatal, merah, edema, berair, rasa seperti terbakar dan terdapat sekret yg bersifat mukoid. ${ }^{1-3,5,6,11-14}$ Terjadinya reaksi hipersensitivitas tipe I fase lambat mempunyai karakteristik, yaitu dengan adanya ikatan antara antigen dengan IgE pada permukaan sel mast, maka mediator kimia yang terbentuk kemudian akan dilepaskan seperti 
histamin, leukotrien $\mathrm{C}_{4}$ dan derivat-derivat eosinofil yang dapat menyebabkan inflamasi di jaringan konjungtiva. ${ }^{5,8,11}$ Reaksi hipersensitivitas tipe IV, terjadi karena sel limfosit $T$ yang telah tersensitisasi bereaksi secara spesifik dengan suatu antigen tertentu, sehingga menimbulkan reaksi imun dengan manifestasi infiltrasi limfosit dan monosit (makrofag) serta menimbulkan indurasi jaringan pada daerah tersebut. ${ }^{14}$ Setelah paparan dengan alergen, jaringan konjungtiva akan diinfiltrasi oleh limfosit, sel plasma, eosinofil dan basofil. Bila penyakit semakin berat, banyak sel limfosit akan terakumulasi dan terjadi sintesis kolagen baru sehingga timbul nodul-nodul yang besar pada lempeng tarsal. ${ }^{4-6,12}$ Aktivasi sel mast tidak hanya disebabkan oleh ikatan alergen IgE, tetapi dapat juga disebabkan oleh anafilatoksin, IL-3 dan IL-5 yang dikeluarkan oleh sel limfosit. Selanjutnya mediator tersebut dapat secara langsung mengaktivasi sel mast tanpa melalui ikatan alergen IgE. ${ }^{5}$ Reaksi hiperreaktivitas konjungtiva selain disebabkan oleh rangsangan spesifik, dapat pula disebabkan oleh rangsangan non spesifik, misal rangsangan panas sinar matahari, angin., $, 9,13,14$

Gejala klinis utama adalah rasa gatal yang terus menerus pada mata, mata sering berair, rasa terbakar atau seperti ada benda asing di mata. ${ }^{6}$ Gejala lainnya fotofobia, ptosis, sekret mata berbentuk mukus seperti benang tebal berwarna hijau atau kuning tua. ${ }^{9} \mathrm{KV}$ dapat terjadi pada konjungtiva tarsalis atau limbus, atau terjadi bersamaan dengan dominasi pada salah satu tempat tersebut. Pada konjungtiva tarsalis superior dapat dijumpai gambaran papil cobblestone yang menyerupai gambaran mozaik atau hipertrofi papil. Sedangkan pada limbus dijumpai satu atau lebih papil berwarna putih yang disebut sebagai trantas dots, yaitu terdiri dari tumpukan sel-sel eosinofill. ${ }^{4-6,9}$ Apabila penyakit meluas sampai kornea, disebut sebagai keratokonjungtivitis vernalis $(\mathrm{KKV})$ dan digolongkan ke dalam penyakit yang lebih berat, karena dapat menyebabkan penurunan visus. ${ }^{6}$

Pada pemeriksaan laboratorium didapatkan kadar IgG serum, IgE serum dan air mata, kadar histamin serum dan air mata meningkat; dan adanya $\operatorname{IgE}$ spesifik. ${ }^{9,11}$ Pemeriksaan mikroskopik dari scraping konjungtiva, patognomonik KV bila dijumpai $>2$ sel eosinofil dengan pembesaran lensa objektif 40x. ${ }^{9,11}$ Gambaran histopatologik jaringan konjungtiva pada KV dijumpai sel eosinofil, sel mast dan sel basofil. Selain itu juga terjadi perubahan pada mikrovaskular dari sel endotel serta ditemukannya deposit jaringan fibrosis, infiltrasi sel limfosit dan netrofil. ${ }^{4,6}$

Diagnosis ditegakkan berdasarkan gambaran klinis, adanya riwayat atopi, dan pemeriksaan penunjang. ${ }^{2,9}$ Hasil uji kulit umumnya positif terhadap alergen tertentu, terutama serbuk bunga, debu rumah, tungau debu rumah; namun kadang-kadang uji kulit dapat memberikan hasil yang negatif. ${ }^{8-10}$

Pada kasus ini terdapat keluhan mata merah, gatal, berair, mengeluarkan sekret, dan riwayat atopi berupa rinitis alergi. Ditemukannya papil cobblestone di konjungtiva tarsalis superior dan terdapatnya peningkatan jumlah eosinofil pada scraping konjungtiva merupakan tanda patognomonik KV. Hasil laboratorium menunjukkan peningkatan hitung eosinofil total $>300 / \mathrm{mm}^{3}$. Hal ini menunjukkan bahwa pasien mempunyai atopi. Pada pasien ini hasil uji kulit positif terhadap debu rumah, tungau debu rumah, udang dan kapuk. Hasil uji kulit positif menunjukkan bahwa pasien telah mengalami sensitisasi dengan alergen tersebut, maka perlu dilakukan pemeriksaan IgE spesifik untuk memastikan penyebab KVnya. Pada kasus ini direncanakan pemeriksaan IgE spesifik terhadap debu rumah dan tungau debu rumah karena merupakan penyebab tersering. Hasil IgE spesifik serum terhadap tungau debu rumah pada pasien ini meningkat. Hal ini menunjukkan bahwa salah satu penyebab KV pada pasien ini adalah tungau debu rumah, namun tidak dapat disingkirkan penyebab lain berupa debu rumah (karena tidak diperiksa) dan faktor fisik lain yaitu panas sinar matahari, angin.

Diagnosis banding KV adalah konjungtivitis alergika musiman, keratokonjungtivitis atopik, dan giant papillary conjungtivitis. ${ }^{4,6}$ Pada konjungtivitis alergi musiman, bersifat akut, mereda saat musim dingin, terdapat edem konjungtiva, jarang disertai perubahan pada kornea. Pada keratokonjungtivitis atopik tidak ada perbedaan usia atau jenis kelamin, adanya sekret yang jernih, letak kelainan lebih sering di palpebra inferior, tidak terdapat eosinofil pada scraping konjungtiva, Pada giant papillary conjunctivitis kelainan juga terdapat di konjungtiva tarsal superior namun dengan ukuran diameter papila yang lebih dari $0,3 \mathrm{~mm}$, penyebab tersering iritasi mekanik yang lama terutama karena penggunaan lensa kontak. ${ }^{4,6}$

Pada umumnya KV dapat sembuh sendiri setelah 2 - 10 tahun. $^{6}$ Tujuan pengobatan pada KV untuk menghilangkan gejala dan menghindari efek iatrogenik yang serius dari obat yang diberikan (kortikosteroid). Prinsip pengobatan bersifat konservatif. Tata laksana konjungtivitis vernalis berdasarkan beratnya gejala dan tanda penyakit, yaitu

1. Terapi utama : berupa penghindaran terhadap semua kemungkinan alergen penyebab. ${ }^{5,6}$ 
2. Terapi topikal Pemberian vasokonstriktor topikal dapat mengurangi gejala kemerahan dan edem pada konjungtiva. Namun pada beberapa hasil penelitian menunjukkan bahwa penggunaan kombinasi obat vasokonstriktor dan antihistamin topikal (vasocon A) mempunyai efek yang lebih efektif dibanding pemberian yang terpisah., ${ }^{5,6}$ Pemberian stabilisator sel mast yaitu natrium kromoglikat 2\% atau sodium kromolyn $4 \%$ atau iodoksamid trometamin dapat mencegah degranulasi dan lepasnya substansi vasoaktif, sehingga dapat mengurangi kebutuhan akan kortikosteroid topikal. ${ }^{3,5,6,15}$ Pemakaian iodoksamid dikatakan mempunyai efek yang lebih baik dibandingkan dengan natrium kromoglikat 2\% maupun sodium kromolyn $4 \%{ }^{6}$

Pemberian obat antiinflamasi non-steroid topikal seperti diklofenak, suprofen, flubirofen dan ketorolak dapat menghambat kerja enzim siklooksigenase, namun saat ini hanya ketorolak yang mendapat rekomendasi dari Food Drug Administration.$^{6}$ Bila obat-obatan topikal seperti antihistamin, vasokonstriktor, atau sodium kromolyn tidak adekuat maka dapat dipertimbangkan pemberian kortikosteroid topikal. Allansmith melaporkan bahwa pemberian terapi "pulse" dengan deksametason 1\% topikal, diberikan tiap 2 jam, 8 kali sehari kemudian diturunkan secara bertahap selama 1 minggu, dapat mengobati inflamasi pada KV, tetapi bila tidak dalam serangan akut pemberian steroid topikal tidak

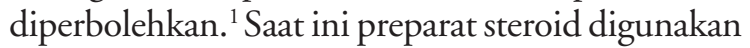
dengan cara injeksi supratarsal pada kasus KV yang refrakter. ${ }^{5,6}$ Siklosporin bekerja menghambat aksi interleukin 2 pada limfosit $T$ dan menekan efek sel $T$ dan eosinofil, terbukti bermanfaat menurunkan gejala dan tanda $\mathrm{KV} ., 6,8$ Terapi untuk kasus berulang yang tidak dapat diobati dengan natrium kromoglikat atau steroid, diberikan siklosporin topikal $2 \%$ dan mitomisin-C topikal 0,01\%.3,-8

\section{Terapi sistemik}

Pengobatan dengan antihistamin sistemik bermanfaat untuk menambah efektivitas pengobatan topikal. Pemberian aspirin dan indometasin (golongan antiinflamasi non-steroid) yang bekerja sebagai penghambat enzim siklooksigenase dilaporkan dapat mengurangi gejala KV., ${ }^{5,6}$ Kortikosteroid sistemik diberikan bila ada indikasi khusus yaitu inflamasi berat pada kornea dan konjungtiva, bertujuan untuk mencegah kerusakan jaringan. ${ }^{6}$ Pemberian montelukas dilaporkan dapat mengurangi gejala pada pasien KV yang juga menderita asma atau pada pasien yang mempunyai risiko terhadap terapi steroid. Namun hal ini masih dalam perdebatan. ${ }^{10}$ Efektivitas pemberian imunoterapi sebagai terapi alergi pada mata sampai saat ini belum memberikan hasil yang memuaskan. ${ }^{6}$

4. Terapi suportif 5,6

- Desensitisasi dengan alergen inhalan.

- Kompres dingin pada mata dan menggunakan kacamata hitam.

- Tetes mata artifisial dapat melarutkan alergen dan berguna untuk mencuci mata

- Klimatoterapi seperti pendingin udara di rumah atau pindah ke tempat berhawa dingin.

5. Terapi bedah

Terapi bedah yang dapat dilakukan adalah otograf konjungtiva dan krio terapi, namun kelemahan kedua terapi ini dapat menyebabkan terjadinya sikatriks, trikiasis, defisiensi air mata dan entropion. ${ }^{6,10}$ Keratotomi superfisial dapat dilakukan untuk reepitelisasi kornea. ${ }^{6}$

Tata laksana yang diberikan pada pasien ini adalah menghindari penyebab dengan cara mengurangi frekuensi bermain di luar rumah, menjaga kebersihan lingkungan, memakai kacamata hitam, diberikan kortikosteroid topikal, stabilisator sel mast (iodoksamid) topikal, dan terapi sistemik berupa antihistamin, dan kortikosteroid. Kortikosteroid topikal dan sistemik diberikan karena saat ini pasien termasuk dalam derajat penyakit sedang ke berat. Penggunaan stabilisator sel mast perlu diberikan dalam jangka panjang (4-6 bulan) untuk mencegah kekambuhan.

Komplikasi yang timbul dapat diakibatkan oleh perjalanan penyakitnya atau efek samping pengobatan yang diberikan. Bila proses penyakit meluas ke kornea, dapat terjadi parut kornea, astigmatisme, keratokonus, dan kebutaan., ${ }^{4,16}$ Penggunaan kortikosteroid jangka panjang dapat menyebabkan glaukoma, katarak dan infeksi bakteri sekunder. ${ }^{3}$ Komplikasi yang terjadi pada pasien ini yaitu adanya bintik-bintik epitelial di kornea dan sikatriks di tengah kornea mata kiri yang disebabkan karena pasien sering menggosok-gosok matanya. Hal tersebut dapat mengakibatkan terjadi penurunan 
visus. Hasil pemeriksaan visus pada pasien ini belum dapat disimpulkan karena saat ini kondisi mata pasien sedang dalam keadaan akut. Seharusnya kejadian tersebut dapat dicegah bila pasien atau orangtuanya mendapat penjelasan tentang cara menghindari komplikasi penyakitnya sejak awal.

Walaupun penyakit ini termasuk self-limiting, namun bila proses keratokonjungtivitis tidak dapat teratasi maka prognosisnya menjadi buruk.

\section{Daftar Pustaka}

1. Allansmith MR. Vernal conjungtivitis. Dalam: Tasman W, Jaeger EA, penyunting. Duane's Clinical Ophthalmology. Philadelphia: Lippincott Ra-Ven, 1997. h. 1-8.

2. Wright KW. Vernal conjungtivitis. Dalam: Wright KW, Buckley EG, Del Monte MA, penyunting. Pediatric Ophthalmology and Strabismus. St Louis: Mosby, 1995. h. 285-6.

3. Pucci N, Novembre E, Cianteronia, Lombardi E, Bernardini R, Caputo R, dkk.Efficacy and safety of cyclosporin eyedrops in vernal keratoconjunctivitis. Ann Allergy Asthma Immunol 2002;89:298-303.

4. Majmuder PA. Conjunctivitis allergic. Didapat dari URL:http//www.emedicine.com pada tanggal 16 Agustus 2003.

5. Bielory L. Allergic and immunology disorders of the eye. Part II: ocular allergy.J Allergy Clin Immunol 2000; 106:805-16.

6. Bonini S, Bonini S, Schiavone M, dkk : Conjuntival Hyperres Ponsivenes To Ocular Histamine Challenge In Patients With Vernal Conjunctivitis. J Allergy Clin Immunol 192 ; 89:103-7. Dikutip dari Lee Y, Raizman MB. Vernal conjunctivitis. Dalam: Bielory L, penyunting. Immunology and Allergy Clinics of North America. Philadelphia: WB Saunders company, 1997. h. 33-52.

7. Foundation of the American Academy of ophthalmology clinical approach to immune-related disorders of the external eye. Dalam: Thomas JL, Thomas AD, M. Gilbert, penyunting. External disease and cornea. San Fransisco: Foundation of the American Academy of Ophthalmology; 2001. h. 194-7.

8. Katelaris $\mathrm{CH}$. Ocular allergy: Implications for the clinical immunologist. Allergy Asthma Immunol 2003; 90:23-7

9. Bonini S. Vernal keratoconjunctivitis revisited: a case series of 195 patients with long-term follow up. Ophthalmol 2000; 107:1157-63.

10. Lambiase A, Bonini S, Rasi G, Coassin M, Bruscolini A, Bonini S. Montelukast, a leukotriene receptor antagonist, in vernal keratoconjunctivitis associated with asthma. Arch Ophthalmol 2003; 121:615-20

11. D'Ermo F, Bonini S, Todini V. Inflamatory cells in conjungtiva scrapings of patient with vernal conjungtivitis. Dalam: Secchi AG, Fregona IA, penyunting. Modern trends in Immunology and Immunopathology of the eye. Milano: Masson; 1989. h. 395-8.

12. Allansmith MR, Hahn GS, Simon MA. Tissue, tear and serum IgE concentration in vernal conjungtivitis. Am J Ophthalmol 1976; 81:506-11.

13. Kresno SB. Penyakit Alergi. Dalam: Kresno SB, penyunting. Imunologi: diagnosis dan prosedur laboratorium. Jakarta: FKUI, 1991. h. 133-43.

14. Munazir Z, Suyoko D. Reaksi Hipersensitivitas. Dalam: Arwin A, Corry SM, penyunting. Buku Ajar Alergi Imunology Anak. Jakarta: BP IDAI, 1997. h. 78-94.

15. Leonardi. A, Borghesan F, Avarello A, Plebani M, Secchi AG. Effect of iodoxamide and sodium cromoglycate on tear eosinophil cationic protein in vernal keratoconjunctivitis. Br J Ophthalmol 1997; 81:23-6.

16. Tobbara KF. Ocular complications of vernal keratoconjunctivitis. Can J Ophthalmol 1999; 34:88-92 